\title{
The UK Nuclear Decommissioning Authority
}

\author{
By
}

Steve Thomas

December 2004

Public Services International Research Unit (PSIRU),

Business School, University of Greenwich, Park Row, London SE10 9LS, U.K.

Email: psiru@psiru.org Website: www.psiru.org Tel: +44-(0)208-331-9933 Fax. +44 (0)208-331-8665

Director: David Hall Researchers: Robin de la Motte, Jane Lethbridge, Emanuele Lobina, Steve Thomas

PSIRU's research is centred around the maintenance of an extensive database on the economic, political, financial, social and technical experience with privatisation and restructuring of public services worldwide, and on the multinational companies involved. This core database is financed by Public Services International ( www.world-psi.org), the worldwide confederation of public service trade unions. PSIRU's research is published on its website, www.psiru.org . 


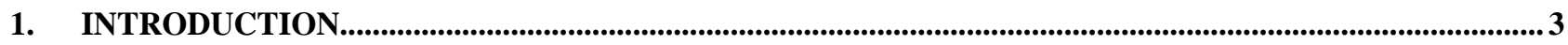

2. WHAT IS THE COMMISSION CASE ABOUT? ....................................................................................... 3

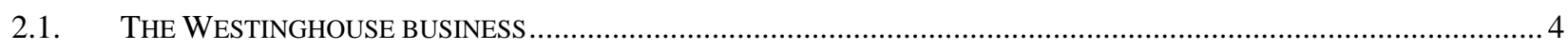

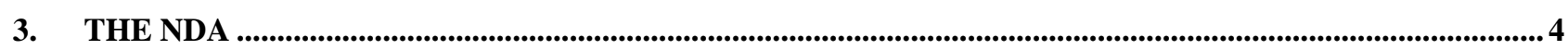

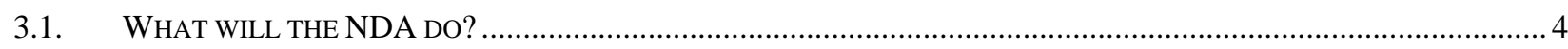

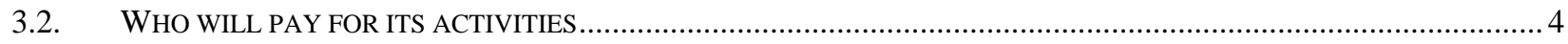

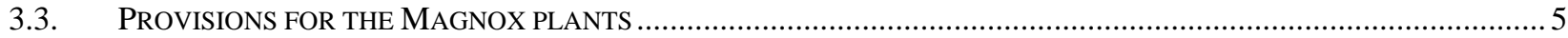

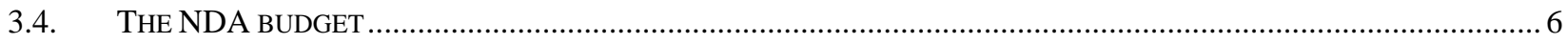

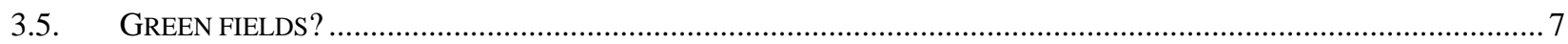

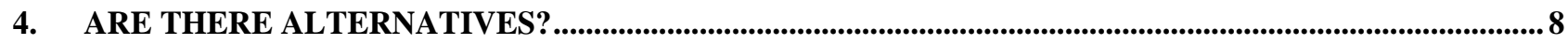

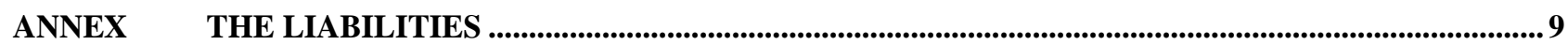

BNFL SITES AREA SITES. 


\section{Introduction}

On December 12004 the European Commission announced it would launch an investigation into Britain's new Nuclear Decommissioning Authority (NDA) to establish whether it would break European Union law by providing illegal state aid to BNFL. ${ }^{1}$ The NDA would inherit most of the liabilities of British Nuclear Fuels Limited (BNFL) and the UKAEA, which would be absolved from the responsibility to meet these liabilities. $^{2}$

The Commission investigation will be interpreted by many as the Commission once again interfering in national affairs. By doing this, it could prevent the British government from finally taking responsible control of the decommissioning of nuclear facilities, an issue that has been variously, ignored, mishandled and even financially exploited by government over the entire history of nuclear power in Britain. However, a closer look at the NDA, what it will do and where it will get its funds from suggest that there is plenty to complain about with the NDA. Consumers and taxpayers have arguably already paid twice over for decommissioning the Magnox plants and under the provisions of the Energy Act 2004 that allowed the setting up of the NDA, future taxpayers will have to pay a third time.

\section{What is the Commission case about?}

The Commission's concern is the BNFL would be given an unfair advantage in competitive markets. As UKAEA is not operating in commercial markets, there is no problem with the transfer of their liabilities. State aids are illegal in principle under European Union law because they 'distort or threaten to distort competition by favouring certain firms or the production of certain goods'. They can be allowed: 'provided it can be clearly proved that the negative impact of the aid on trading conditions is outweighed by its positive contribution to the fulfilment of other Community objectives. ${ }^{3}$ There is a strange anomaly about how the case is being discussed. The British government stated that it had informed the European Commission that it would be providing state aid in December 2003, although it said this was for the NDA, not BNFL. Since it is BNFL that is being relieved of its liabilities, it is hard to see how the aid could be said to be going to the NDA. In response to the Commission's announcement the DTI stated: 'The Government today welcomed the beginning of the European Commission's formal investigation into State aid to the NDA. ${ }^{4}$ By contrast, the Commission's press release makes it clear that it is investigating whether BNFL would be receiving state aid.

The issue is that BNFL would be split into two parts, the part with the liabilities would pass to the NDA, while the rest, particularly the Westinghouse fuel supply, and reactor supply and servicing business, could then carry on and perhaps be privatised, unencumbered by these liabilities. In the Commission's words: 'The transfer of the first part to the NDA will be done at no cost to BNFL, that will continue normal commercial operations, although this transfer will relieve it from nuclear liabilities that it should normally have met under the "polluter pays" principle.'

The British government claims that BNFL's own resources, presumably the Nuclear Liabilities Investment Portfolio (NLIP) discussed below, will give the NDA ample resources to start its work on April 12005 and continue until well after the Commission delivers its verdict. As these resources are deemed to be BNFL's own funds, there is no issue of state aid with these and the start-up of the NDA will not be delayed.

\footnotetext{
${ }^{1}$ European Commission (2004) 'State aids: Commission opens formal investigation into UK Nuclear Decommissioning Authority’ IP/04/1430, 01/12/2004, Brussels. (see http://europa.eu.int/rapid/pressReleasesAction.do?reference=IP/04/1430\&format=HTML\&aged=0\&language=EN\&gui Language=en)

${ }^{2}$ The British government had informed the European Commission that it would be providing state aid in December 2003, although it said this was for the NDA, not BNFL. Since it is BNFL that is being relieved of its liabilities, it is hard to see how the aid could be said to be going to the NDA.

${ }^{3}$ European Commission (2004) 'State aids: Commission opens formal investigation into UK Nuclear Decommissioning Authority’ IP/04/1430, 01/12/2004, Brussels.

${ }^{4}$ Department of Trade \& Industry (2004) 'Nuclear Decommissioning Authority (NDA) still on track for April 2005 start' Press Release P/2004/446. December 1, 2004.
} 


\subsection{The Westinghouse business}

The Westinghouse business was acquired mainly in 1998-99 when it bought three of the world's major nuclear power plant vendors. It bought the nuclear power division of the US Westinghouse company in 1998 and the nuclear division of Swedish/Swiss company ABB in 1999. ABB had already bought another US vendor, Combustion Engineering. These acquisitions made BNFL one of the two major reactor vendors and it claims to be the largest nuclear fuel supplier worldwide.

These acquisitions took place at a time when BNFL was in the curious position of having huge liabilities but was awash with cash from advance payments for reprocessing fuel for foreign clients at its THORP plant in Sellafield. In 2003/04, Westinghouse made a profit of $£ 52 \mathrm{~m}$ on turnover of $£ 1125 \mathrm{~m}$ and there is an expectation that if the business was made available, buyers would come in.

\section{The NDA}

\subsection{What will the NDA do?}

The NDA was set up following publication of the UK government 2002 White Paper, 'Managing the nuclear legacy: A strategy for action'. ${ }^{5}$ Under this, a Liabilities Managing Unit (LMU) was set up within the DTI, employing about 20 people. The job of the LMU was to prepare the ground for the establishment of a Liabilities Management Authority (LMA), later renamed the Nuclear Decommissioning Authority (NDA). This would inherit sites from the UKAEA and BNFL and manage their clean-up. It would use competitive processes to allocate clean-up jobs so although BNFL and UKAEA would lose ownership of their sites, they would be able to bid to carry out the work.

The NDA was established on July 22, 2004 under the 2004 Energy Act ${ }^{6}$ and it will continue in shadow form until it formally commences operations on April 1, 2005. It will inherit most of BNFL's assets including the Sellafield and Capenhurst sites, the Magnox power stations (11 sites), the Springfield fuel manufacturing plant and the Drigg waste disposal site. It will also take on the UKAEA sites, those that were left in public ownership when the saleable part of UKAEA was privatised. These include sites of prototype reactors (Dounreay, Windscale and Winfrith) and other sites (Culham and Harwell). The total undiscounted cost of the liabilities it will inherit were estimated by the NDA to be $£ 50 \mathrm{bn}$.

\subsection{Who will pay for its activities}

The 2002 White Paper raised the issue for long-term nuclear liabilities of continuity of funding and the shortterm nature of any funding commitments the government can make under three-year spending reviews. It acknowledged that 'in the past, nuclear clean up has also been seen as a low priority for funding purposes relative to other programmes. Experience to date with UKAEA has therefore been that settlements have tended to be the minimum necessary to address safety and environmental needs and that limited funding has been available for other projects'

It offered two options for the NDA as ways to provide greater assurance, a 'segregated fund' and a 'statutory segregated account'. The segregated fund would be an identifiable set of assets managed in much the same way as a pension fund. Of course, a key difference between a nuclear segregated fund and a pension fund is that people putting money into pension funds expect to benefit personally from their contributions.

Worldwide, it is the preferred method of securing decommissioning funds, because it insulates the funds from the fortunes of the company - if the company goes bust, the funds do not go with it - and it is a pot of money that is more tangible to the public than a company promise. However, for the government to set up a segregated fund would go against government policy. Under this the Treasury has always resisted efforts to earmark funds, preferring to have maximum flexibility to use funds in whatever way it sees fit. The Treasury argues that this allows it to get the best return on the money at its disposal.

\footnotetext{
${ }^{5}$ Department of Trade \& Industry (2002) 'Managing the Nuclear Legacy: A strategy for action' cm 5552, Department of Trade \& Industry, London (see http://www.dti.gov.uk/nuclearcleanup/pdfs/whitepaper.pdf)

${ }^{6}$ Her Majesty's Government (2004) 'The Energy Act 2004' HMSO, London (see http://www.legislation.hmso.gov.uk/acts/acts2004/20040020.htm)
} 
A segregated account would require annual notional payments from tax income towards clean-up and would represent a statutory commitment to fund decommissioning but the money would not be in a separate identifiable pot. Government would merely provide statutory assurances that the money committed would be available when required. In practice, the government would simply be writing 'IOUs' and the government would be able to use the money as it wished until it was actually required. Clearly the latter would be the Treasury's preferred alternative.

The White Paper spends several pages arguing the pros and cons of these two options but omits any discussion of what appear to be two much more important issues: the time-scale and the 'polluter pays' principle.

A third of BNFL's liabilities are not expected under its plans to fall due until 50-150 years from now. It stretches credibility to the limit to assume that a segregated fund created by a private company is sure to survive intact, earning interest at the assumed rate for a century forward. But assuming a government will not be tempted to get its hands on such a tempting pot of money for 150 years is perhaps even more implausible. Current government can set up any legal provisions it likes, but it cannot commit that a future government will not repeal all these assurances and, make off with the cash for whatever purposes it chose. If, God forbid, there was a major war, would government really resist the temptation to grab these funds to defend the country?

However, it is the 'polluter pays' principle and, to a lesser extent, the 'precautionary principle' that is conspicuously absent from the argument. The OECD was the first governmental organisation to espouse the polluter pays principle and its 1992 definition is:

'The polluter should bear the costs of pollution prevention and control measures, and that these measures should be decided by public authorities to ensure that the environment is in an acceptable state.'

In 1999, the British government published its policy on sustainability, 'A better quality of life: a strategy for sustainable development for the $\mathrm{UK}^{, 7}$, which also espoused the polluter pays and the precautionary principle. It adopted the definition from the 1992 Rio Declaration which defines the precautionary principle as 'where there are threats of serious or irreversible damage, lack of full scientific certainty shall not be used as a reason for postponing cost-effective measures to prevent environmental degradation.'

Remarkably, these two principles do not appear once in the 2002 White Paper. The implication of the polluter pays principle in the case of decommissioning nuclear power plants seems clear. Electricity consumers should pay for the decommissioning of the plants, so that the fund, however it is kept, should contain enough money at the end of the life of the plant to ensure that decommissioning can be paid for. How far investment income from the fund after plant closure should be assumed to contribute to the cost is another issue we will come back to.

Neither scheme offered by government comes close to the polluter pays ideal. Contributions would be annual, from tax income and would be calculated on the basis of short-term need. If there was no need for funds, no contribution would be made and taxpayers 150 years from now would still be paying to clean up our nuclear power stations.

\subsection{Provisions for the Magnox plants}

Electricity consumers have already paid for the decommissioning of the Magnox plants. In the 1989 preprivatisation accounts of the Central Electricity Generating Board (CEGB) and the South of Scotland Electricity Board (SSEB), £3.8bn of assets was set against the decommissioning liability. Taking account of inflation and allowing, say, $3 \%$ annual real rate of return, this sum should have about doubled by now. This notional amount was simply absorbed by government when the industry was privatised and was used to subsidise government spending.

\footnotetext{
7 'A better quality of life: a strategy for sustainable development for the UK' (Cm 4345, The Stationery Office, London, ISBN 0-10-143452-9
} 
There was also the Fossil Fuel Levy, which was a sum paid by electricity consumers (10\% of their electricity bills) from 1990-98, to which electricity consumers contributed about £8bn. Michael Heseltine told Parliament this was 'to decommission old unsafe stations'. In fact, it was used for almost anything but that, and paid for a new nuclear power plant (Sizewell B) and was unrestricted cash income for Nuclear Electric to pay for its losses. Despite its best efforts, Nuclear Electric, the nationally owned company that inherited all the CEGB's nuclear assets, did not manage to spend it all and $£ 2.7 \mathrm{bn}$ remained unspent when the nuclear industry was reorganised in 1996. A small amount went to British Energy's (the privatised company that inherited the more modern nuclear plants) segregated decommissioning fund and the rest went to BNFL, who inherited the Magnox plants. There, it was placed in the Nuclear Liabilities Investment Portfolio (NLIP), a fund that was separately identified in BNFL's accounts, but not strictly segregated. So if BNFL had faced bills it could not otherwise have paid, it would have to have drawn this fund down. The NLIP, with inflation and some capital growth now stands at about £4bn.

Two of the Magnox stations were primarily built for military purposes to produce plutonium for bombs and therefore arguably not the responsibility of electricity consumers, leaving nine civil plants. If we assume that a Magnox plant costs about $£ 1.1 \mathrm{bn}$ to decommission, it seems clear that consumers have already paid more than enough to discharge their responsibility under the polluter pays principle, and that government took most of that money for its own purposes. All that remains of the Magnox provisions is the £4bn in the NLIP. This would not be enough to pay for Magnox decommissioning but would be sufficient on projected levels of spending at the NDA and with a little interest on investment to fund about 20 years worth of work decommissioning them.

\subsection{The NDA budget}

The Treasury, ever eager to find ways to fund its work without taking money from taxpayers, was not slow to spot the NLIP and in the White Paper, the government foresaw the NLIP as the initial payment into the segregated fund or the segregated account that would fund NDA's overall programme. This seemed on the face of it to have guarded against the government just absorbing it in return for a promise to deal with the clean-up problem. However, it clearly did not meet the polluter pays principle. Why should money contributed by electricity consumers for decommissioning Magnox plants go to clear up the mess of military programmes, prototype reactors and reprocessing plants? At least the White Paper did promise that the fund or account would not subsidise running costs at the facilities still in operation. It said: 'The operation of the commercial assets - THORP, SMP and the operational Magnox stations - inherited from BNFL would be funded separately. The fund would not underwrite their operation.'

Predictably, when the Energy Bill of 2004 was passed, the hand of the Treasury was all to clear. The segregated fund option was not chosen and a segregated account, the Nuclear Decommissioning Funding Account (NDFA) was set up with the NLIP as its initial endowment. Since the NDFA is not a tangible fund, in practice this means that current taxpayers are not being asked to fund anything other than the work that is actually carried out and effectively future taxpayers will pay when the work is required.

In fact, under the Energy Act 2004, the government paid the NLIP into the Consolidated Fund (the government's general income) with a promise to fund the NDA. With the NDA's annual budget expected to be about $£ 2$ bn, the NLIP would cover about 2 years of operation. However, the DTI stated: 'Of this [the $£ 2$ bn annual budget], over $£ 1$ billion per year will be provided through DTI's Departmental Expenditure Limit', so government appeared not to be raiding the NLIP to subsidise operation.

If we look at the NDA's proposed budget for its first year (see Table), about half of its expenditure will go on running costs. Of this, $£ 480 \mathrm{~m}$ would go to fund Sellafield operations, $£ 380 \mathrm{~m}$ to fund the Magnox plants and $£ 130 \mathrm{~m}$ for the Springfields fuel manufacture site. In its first year of operation, the NDA expects to receive $£ 1084 \mathrm{~m}$ as 'funds equivalent to forecast receipts from income-generating activities'. This $£ 1084 \mathrm{~m}$ is made up of about $£ 635 \mathrm{~m}$ from reprocessing, $£ 307 \mathrm{~m}$ from electricity generation and the rest $(£ 137 \mathrm{~m})$ from fuel manufacture (MOX and AGR). So the Magnox plants are expected to make a loss even on only operating cost of about $£ 70 \mathrm{~m}$. However, $£ 119 \mathrm{~m}$ of this running cost is for closed plants, presumably to pay for the processing of the fuel remaining in the plant at the end of its life, so the remaining operating Magnoxes are expected to at least cover their costs. 
The rest of NDA's income comes from two sources: $£ 675 \mathrm{~m}$ as: 'funds equivalent to those transferred from BNFL', i.e., the transfer from the NLIP, and only $£ 503 \mathrm{~m}$ from government. Given that government will absorb the NLIP from April 1 2005, the $£ 503 \mathrm{~m}$ from government arguably comes from the NLIP - the NLIP was marginal income to the government and the budget to the NDA is marginal expenditure.

It is difficult to sort out how well the other activities cover their running costs as the MOX plant is at the Sellafield site and its running costs are presumably included there while the income from AGR (manufactured at Springfields) and MOX fuel manufacture is not separated. However, the Independent on Sunday (December 12, 2004) did report that confidential figures suggested that income for the MOX plant would exceed expenditure in 2005 by $£ 45 \mathrm{~m}$.

Given the unreliability of the THORP reprocessing plant, the fast ageing of the Magnox plants and the dismal history of the MOX plant going over budget and not working reliably ${ }^{8}$, it will be no surprise if the income falls short of the forecast and government will have to find more (effectively drawing down the NLIP quicker).

\subsection{Green fields?}

The other aspect that deserves a little examination is the end-point of the clean-up process. Those that had in mind that the decommissioning process would end up with 'green-field' sites, i.e. sites with unrestricted usage including food production, will be disappointed. This is despite the fact that the polluter pays principle suggests that is where the process should end. Most definitions of this principle require the restoration of the environment to an 'acceptable' state. A guarded restricted area would not come under most peoples' definition of an acceptable state. If we look at BNFL and UKAEA's reports, it is clear this is not contemplated and problematic facilities like Dounreay and Sellafield will need to be restricted for hundreds of years.

BNFL characteristically justifies this by pointing out that other industries seem able to get away with such an inadequate job, so why should it do better. It states ${ }^{9}$ :

The Board of BNFL has long estimated its provisions for decommissioning and waste management on the assumption that the existing plants and buildings are demolished and sites are cleared, but not to the extent that the sites would be returned to farmland. This reflects the approach which industry typically follows where there is no requirement in law or otherwise to do more than ensure that an industrial site is made safe.

Whether there is a realistic alternative to this (i.e., the site could be cleaned up to green-field status if enough money was spent) is hard to determine, but if NDA is to avoid inheriting BNFL's reputation, it is an option it needs to examine.

Table

The NDA's draft budget

\begin{tabular}{|l|l|l|l|l|}
\hline Facility & $\begin{array}{l}\text { Undiscounted } \\
\text { liability (£bn) }\end{array}$ & $\begin{array}{l}\text { Decommissioning/ } \\
\text { clean up costs } \\
\mathbf{2 0 0 5 / 0 6} \mathbf{~ f m ~}\end{array}$ & $\begin{array}{l}\text { Operating costs } \\
\mathbf{2 0 0 5 / 0 6} \mathbf{\text { fm }}\end{array}$ & $\begin{array}{l}\text { Total expenditure } \\
\mathbf{2 0 0 5 / 0 6}\end{array}$ \\
\hline BNFL & $\mathbf{4 0 . 3}$ & $\mathbf{8 3 9 . 7}$ & $\mathbf{9 9 3 . 6}$ & $\mathbf{1 8 3 3 . 5}$ \\
\hline Sellafield inc Drigg & $\mathbf{2 7 . 5}$ & $\mathbf{5 5 1 . 7}$ & $\mathbf{4 8 3 . 6}$ & $\mathbf{1 0 3 5 . 3}$ \\
\hline Berkeley & 1.1 & 39.1 & 0 & 39.1 \\
\hline Bradwell & 1.1 & 24.9 & 39.8 & 64.7 \\
\hline Calder Hall & 1.1 & 10.5 & 12.0 & 22.5 \\
\hline Chapelcross & 1.1 & 13.4 & 53.9 & 67.3 \\
\hline Dungeness A* & 1.1 & 5.7 & 53.0 & 58.7 \\
\hline Hinkley Point A & 1.1 & 42.8 & 12.5 & 55.3 \\
\hline Hunterston A & 1.1 & 56.1 & 0 & 56.1 \\
\hline Oldbury* & 1.1 & 0.4 & 53.7 & 54.1 \\
\hline Sizewell A* & 1.1 & 0.4 & 57.3 & 57.7 \\
\hline Trawsfynydd & 1.1 & 45.1 & 0 & 45.1 \\
\hline Wylfa* & 1.1 & 0.6 & 99.2 & 99.8 \\
\hline
\end{tabular}

\footnotetext{
${ }^{8}$ In the Independent on Sunday, May 16, 2004 A BNFL spokesman said: "Despite everyone's best efforts, the bloody thing does not work." He said its design was so complex that it kept breaking down.

${ }^{9}$ BNFL (2004) 'Annual Report and Accounts 2004' p 96, BNFL, Warrington
} 


\begin{tabular}{|l|l|l|l|l|}
\hline Magnox closed & & 231.9 & 118.2 & 350.1 \\
\hline Magnox operating & & 7.1 & 263.2 & 270.3 \\
\hline All Magnox & $\mathbf{1 2}$ & $\mathbf{2 3 9}$ & $\mathbf{3 8 1 . 4}$ & $\mathbf{6 2 0 . 4}$ \\
\hline Capenhurst & $\mathbf{0 . 5}$ & $\mathbf{2 3 . 2}$ & $\mathbf{0}$ & $\mathbf{2 3 . 2}$ \\
\hline Springfields & $\mathbf{0 . 3}$ & $\mathbf{2 5 . 8}$ & $\mathbf{1 2 8 . 6}$ & $\mathbf{1 5 4 . 4}$ \\
\hline UKAEA & $\mathbf{8 . 0 8 3}$ & $\mathbf{2 7 3 . 5}$ & $\mathbf{0 . 9}$ & $\mathbf{2 7 4 . 4}$ \\
\hline Dounreay & $\mathbf{4 . 6 3 6}$ & $\mathbf{1 4 9 . 7}$ & $\mathbf{0}$ & $\mathbf{1 4 9 . 7}$ \\
\hline Windscale & $\mathbf{1 . 7 9}$ & $\mathbf{2 5 . 6}$ & $\mathbf{0 . 9}$ & $\mathbf{2 6 . 5}$ \\
\hline Winfrith & $\mathbf{0 . 5 4 8}$ & $\mathbf{3 7 . 5}$ & $\mathbf{0}$ & $\mathbf{3 7 . 5}$ \\
\hline Harwell & $\mathbf{1 . 1 0 9}$ & $\mathbf{6 0 . 7}$ & $\mathbf{0}$ & $\mathbf{6 0 . 7}$ \\
\hline Culham & $\mathbf{0 . 2 4 9}$ & - & - & - \\
\hline Total & $\mathbf{4 8 . 4}$ & $\mathbf{1 1 1 3 . 2}$ & $\mathbf{9 9 4 . 5}$ & $\mathbf{2 1 0 7 . 7}$ \\
\hline
\end{tabular}

\section{Are there alternatives?}

To a large extent, the Commission investigation is a side-show. The liability exists and there is no way to avoid it falling on taxpayers. It is galling when a company that has left huge debts appears to walk away from them and start up again with a clean sheet - 'change the name and do the same.' However, the value of the Westinghouse assets is dwarfed by the liabilities and most of the business now in the Westinghouse division was acquired after these liabilities were incurred. In ethical terms, the best outcome would be if the Westinghouse business was sold and the proceeds were to be placed in a segregated fund to pay for the clean-up. The Commission tried and failed to pass a Nuclear Directive that would have mandated segregated funds and the Treasury has probably vetoed a segregated fund, so the proceeds of any Westinghouse sale will go into the 'Consolidated Fund' and will allow either tax cuts or increases in general government spending. So as far as paying for the liabilities goes, the Commission's verdict will not change anything significantly.

From an ethical point of view, cleaning up the nuclear sites should be paid for by government now. The 'consumers' of these sites have had the benefits and government has received at least some of the funds to pay for their clean-up. However, expecting the Treasury to surrender about $£ 50 \mathrm{bn}$ overnight $-£ 1000$ per capita - is not realistic. But perhaps over, say, 10 years it could be done.

The issues of timing, end-point of the process, how the funds are kept and the extent to which interest on the funds can be assumed are all interlinked. From a cynical point of view, the long timescale and the assumption that funds earn interest indefinitely are very convenient to the government. To pay a debt of $£ 100$ in 150 years time will only require a deposit of $£ 1.18$ if a real annual interest rate of only $3 \%$ is assumed. But assuming the world will remain such a stable place for this period that interest rates of this level would continue to be available, the skills and resources to carry out the job would be available and that nothing would happen to make accelerating the timetable desirable (e.g., rising water levels) would be heroic. It is hard to avoid the conclusion that the government's commitment to the polluter pays principle is worthless. The job is being done as slowly as possible, to the minimum standard that can be got away with and at the lowest possible cost to the current generation.

If we take the precautionary principle and the polluter pays principle seriously, the approach should surely be to decommission as quickly as possible, consistent with ensuring the safety of those doing the job, to greenfield site status if it is possible and assuming interest for no longer than, say government bonds are available (30 years). A segregated fund that is not reliant on payments from future taxpayers, long into the future does not provide absolute protection against subversion of the funds. However, it certainly represents a more concrete commitment than the 'segregated account', which, ultimately, commits the government to do no more than it would be obliged to do anyway. 


\section{Annex}

\section{The Liabilities}

\section{BNFL sites}

BNFL sites account for about $85 \%$ of the liabilities that the NDA will take on, with an undiscounted value of $£ 41.4 \mathrm{bn}$. Of this, BNFL is liable for nearly $70 \%$, $228.3 \mathrm{bn}$ and of the rest, $28 \%$ is the responsibility of the Ministry of Defence and the UKAEA and $12 \%$ is to be paid by commercial customers. Discounted at $2.5 \%$ a year, the $£ 41.4 \mathrm{bn}$ reduces to $£ 20.5 \mathrm{bn}$. This $£ 41.4 \mathrm{bn}$ is made up of decommissioning (45\%), waste management (48\%) and reprocessing (7\%). In terms of timescales, more than a third is projected to take place more than 60 years in the future. The breakdown given in the most recent annual report was: 20042014, 30\%; 2015-2065, 34\%, 2066-2150, 36\%. The net liabilities of Magnox Electric, essentially decommissioning the plants amount to only $£ 3.7 \mathrm{bn}$ in discounted terms, although in the 2002 government white paper, the undiscounted cost was estimated as £12bn, reflecting the very long time-scale assumed for decommissioning. However, the major component was Sellafield itself (including the Drigg low-level waste disposal site, with a total undiscounted cost of $£ 27.5 \mathrm{bn}$. Other BNFL site costs are relatively small, mainly Capenhurst (0.5bn) and Springfields (0.3bn).

The cost of decommissioning the Magnox sites seems to have escalated substantially in the last decade. In 1996 , each station was estimated to cost about $£ 600 \mathrm{~m}$ to decommission. The stations are all different and some will present different problems to others however, work has already been carried out at some stations, for example, stage 1 decommissioning has been completed at Hunterston A, Berkeley and Trawsfynydd. The remaining liability is about $£ 1.1$ bn per station, nearly double the estimate from a decade ago.

\section{UKAEA sites}

The UKAEA's liabilities were estimated in the UKAEA annual report (2003/04) as an undiscounted sum of $£ 9.39 \mathrm{bn}$. The magic of discounting - assuming that if you need do something in 10 years, you can invest a sum now and earn interest so the sum you need now is less than the actual cost - reduces this figure to $£ 5.07 \mathrm{bn}$. This is up from the 2003 figure of $£ 3.88 \mathrm{bn}$ because the treasury decided that a real interest rate of $6 \%$ was too high and has now required $3.5 \%$ to be used. Of the total discounted costs of $£ 5.07 \mathrm{bn}, £ 4.82 \mathrm{bn}$ is recoverable from the DTI under a Letter of Understanding issued by the then Secretary of State for Energy in May 1986 and confirmed in June 1996. The balance is recoverable from other customers, or financed from up-front payments received by UKAEA.

Given that, on current plans, clean-up will go on for more than 30 years, during which, a great deal can change not least rates of interest available, even the lower discount rate of $3.5 \%$ seems a little optimistic and, for example, BNFL only assumes a discount rate of $2.5 \%$. The latest plans for the five major sites, published in September 2004, yield a significant reduction of the total liability of $£ 8083$ and a bringing forward of the timetable at most sites (the UKAEA claims up to 75\%). Most of the sites are not expected to be brought to green-field status and when active decommissioning work is completed, they will enter a 'passive safety' state. So while the UKAEA shows pretty pictures of how it expects the Dounreay site to look, the reality is that for 300 years after completion of decommissioning, the site would need 'care and surveillance' and would certainly not be open for unrestricted use.

\section{Dounreay}

This is the site of the fast breeder reactor programme and is infamous for the shaft into which all manner of nuclear waste was thrown. Decommissioning is not expected to be complete before 2036 (markedly shorter than earlier estimates which would probably have stretched out till the $22^{\text {nd }}$ century) and the UKAEA has said that the main hazards will be made 'passively safe' in the next 20 years. On the cost of this operation, the UKAEA said it 'will not be cheap' ${ }^{10}$ and that it would cost $£ 2695 \mathrm{~m}$. Reflecting these long time-scales, if the NDA cost escalation factor of $3.3 \%$ is applied, the total cost is estimated to be $£ 4636 \mathrm{~m}$.

\section{Windscale}

This is another infamous site, within the Sellafield complex and housing the Windscale Pile, which was the scene of Britain's worst nuclear accident in 1957 when the Pile caught fire. It also contains the prototype for the AGR programme. In 2004, the estimate cost was about $£ 608 \mathrm{~m}$. Decommissioning to the extent of the site

${ }^{10}$ http://www.ukaea.org.uk/dounreay/restorepdf/dounreay8.pdf 
being made passively safe is expected to be completed in 2017 with final clearance by 2065 , although clearly there is no possibility of the site being released even then. Reflecting these long time-scales, if the NDA cost escalation factor of $3.3 \%$ is applied, the total cost is estimated to be $£ 1790 \mathrm{~m}$.

\section{Winfrith}

This is the site of some prototype reactors and it is expected decommissioning (the site will be "completely cleared') will be completed in 2020 and available for non-nuclear use. The estimated cost is $£ 441 \mathrm{~m}$, which when escalated by the NDA's recommended rate of $3.3 \%$ amounts to $£ 548 \mathrm{~m}$

\section{Harwell}

Harwell is the headquarters of the UKAEA and is the site of numerous prototype reactors and other facilities. It is expected that the site achieve 'a passively safe interim end state by 2015 with completion in 2025 . The total cost is estimated to be $£ 826 \mathrm{~m}$ and if the NDA escalation factor is applied, this increases to $£ 1109 \mathrm{~m}$

\section{Culham}

Culham is the site of the fusion programme research and development programme. The site is still operational and decommissioning work is still at a planning stage. The estimated decommissioning cost is $£ 185 \mathrm{~m}$, which when escalated at $3.3 \%$ amounts to $£ 249 \mathrm{~m}$. 